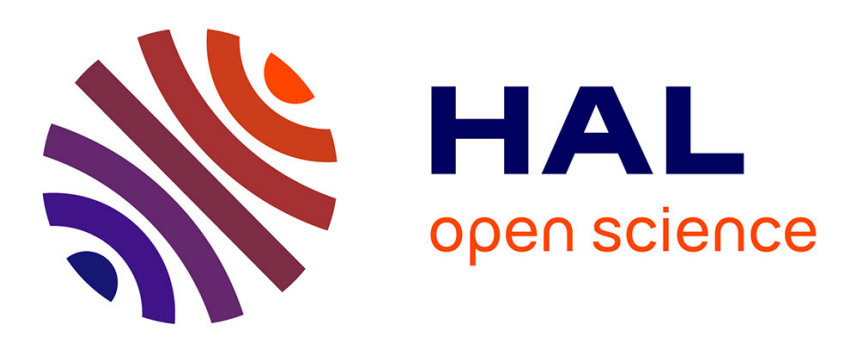

\title{
Direct Comparison of Urea-SCR and NH3-SCR Activities Over Acidic Oxide and Exchanged Zeolite Prototype Powdered Catalysts
}

Michael Seneque, Xavier Courtois, F. Can, Daniel Duprez

\section{To cite this version:}

Michael Seneque, Xavier Courtois, F. Can, Daniel Duprez. Direct Comparison of Urea-SCR and NH3SCR Activities Over Acidic Oxide and Exchanged Zeolite Prototype Powdered Catalysts. Topics in Catalysis, 2016, 59 (10-12), pp.938 - 944. 10.1007/s11244-016-0572-4 . hal-01685566

\section{HAL Id: hal-01685566 https://hal.science/hal-01685566}

Submitted on 22 Jan 2021

HAL is a multi-disciplinary open access archive for the deposit and dissemination of scientific research documents, whether they are published or not. The documents may come from teaching and research institutions in France or abroad, or from public or private research centers.
L'archive ouverte pluridisciplinaire HAL, est destinée au dépôt et à la diffusion de documents scientifiques de niveau recherche, publiés ou non, émanant des établissements d'enseignement et de recherche français ou étrangers, des laboratoires publics ou privés. 


\title{
Direct comparison of Urea-SCR and $\mathrm{NH}_{3}-\mathrm{SCR}$ activities over acidic oxide and exchanged zeolite prototype powdered catalysts.
}

\author{
Michael SENEQUE, Xavier COURTOIS*, F. CAN, Daniel DUPREZ
}

Affiliation: Institut de Chimie des Milieux et des Matériaux de Poitiers (IC2MP), UMR 7285 Université de Poitiers-CNRS, 4 rue Michel Brunet, TSA 51106, F-86073 Poitiers Cedex 9, France

*Corresponding author: Tel.: 33(0)549453994, e-mail: xavier.courtois@univ-poitiers.fr.

\begin{abstract}
In order to develop new NOx selective catalytic reduction (SCR) catalysts for automotive application, the DeNOx catalytic activity is commonly evaluate at the laboratory scale using $\mathrm{NH}_{3}$ as reductant. However, $\mathrm{NH}_{3}$ is not directly used on board: an ammonia precursor based on urea aqueous solution is injected in the exhaust pipe upstream the SCR catalyst. It is admitted that ammonia is then obtained by two successive reactions: the thermal decomposition of urea, leading to $\mathrm{HNCO}$ and $\mathrm{NH}_{3}$, and the $\mathrm{HNCO}$ hydrolysis, providing the second molecule of $\mathrm{NH}_{3}$. However, the complete availability of ammonia from urea could be not achieved before the SCR catalyst. Then, the influence of the SCR catalyst on these reactions may impact the NOx reduction efficiency. With the aim to study the possible role of the SCR catalyst on the ammonia availability, an innovative synthetic gas bench adjusted to powdered material was developed, allowing the direct comparison of the use of gaseous $\mathrm{NH}_{3}$ or urea (injected aqueous solution) for the NOx conversion, depending on the temperature $\left(200-500^{\circ} \mathrm{C}\right)$. This work presents results obtained with an oxide based prototype SCR catalyst in comparison with a patented Fe-exchanged zeolite, evaluated in both standard and fast SCR stoichiometry. This study points out that, in contrast with the exchanged zeolite, the evaluated oxide based catalyst may not allow an optimal NOx conversion because of a lack in ammonia availability, attributed to insufficient activity in HNCO hydrolysis.
\end{abstract}

Keywords: Urea; $\mathrm{NH}_{3}$; SCR; residence time; oxide; zeolite. 


\section{Introduction}

Recent regulations for Diesel or lean-burn engines like Euro 6/VI tend to impose three different catalytic processes to treat the exhaust gas, including (i) an oxidation catalyst for $\mathrm{CO}$ and unburned hydrocarbons, (ii) a particulate filter for soot trapping and combustion, and (iii) a specific process for NOx reduction. Concerning the NOx treatment, two main technologies are usually proposed. The NOx storage reduction (NSR) process works in transient condition, with alternating oxidizing and reducing phases [1]. It doesn't need additional reductant other than fuel, but the main drawbacks are fuel overconsumption, ageing (thermal ageing, poisoning) and NOx reduction selectivity. The second technology is adapted from the NOx selective catalytic reduction (SCR) by ammonia developed in the 1970 ' for stationary source application. The $\mathrm{NH}_{3}$-SCR reactions are mainly known as "standard-SCR" (Eq. 1) and "fast-SCR" (Eq. 2) depending on the $\mathrm{NO}_{2} / \mathrm{NOx}$ ratio, both reactions respecting the $\mathrm{NH}_{3}-\mathrm{NOx}$ stoichiometry $1-1$.

$$
\begin{aligned}
& 4 \mathrm{NH}_{3}+4 \mathrm{NO}+\mathrm{O}_{2} \rightarrow 4 \mathrm{~N}_{2}+6 \mathrm{H}_{2} \mathrm{O} \\
& 4 \mathrm{NH}_{3}+2 \mathrm{NO}+2 \mathrm{NO}_{2} \rightarrow 4 \mathrm{~N}_{2}+6 \mathrm{H}_{2} \mathrm{O}
\end{aligned}
$$

However, the implementation of the $\mathrm{NH}_{3}$-SCR process into passenger cars and heavy duty vehicles requires the use of an ammonia precursor, usually an urea aqueous solution. Ammonia is then obtained by two consecutive reactions: urea thermolysis (Eq. 3) and HNCO hydrolysis (Eq. 4):

$$
\begin{aligned}
& \left(\mathrm{NH}_{2}\right) \mathrm{CO}\left(\mathrm{NH}_{2}\right) \rightarrow \mathrm{NH}_{3}+\mathrm{HNCO} \\
& \mathrm{HNCO}+\mathrm{H}_{2} \mathrm{O} \rightarrow \mathrm{NH}_{3}+\mathrm{CO}_{2}
\end{aligned}
$$

Unfortunately, $\mathrm{NH}_{3}$ may be not fully available due to a limited urea decomposition/hydrolysis. It leads to an imbalance in the SCR stoichiometry and it may cause deposit formation due to formation of biuret, cyanuric acid, ammelide, ammeline...[2].

In addition, the implementation of a particulate filter in the exhaust pipe, which induces strong exothermic reactions, does not allow the use of conventional vanadium based SCR catalysts. To reach the required high thermal stability, new SCR materials are developed. They are usually firstly evaluated in DeNOx efficiency at the laboratory scale in $\mathrm{NH}_{3}$-SCR. However, this is not the on-board reductant, but only few works deal with urea-SCR at the laboratory scale [3,4], especially with powdered catalysts.

In order to evaluate these new catalysts in both urea-SCR and $\mathrm{NH}_{3}-\mathrm{SCR}$ conditions, an innovative experimental synthetic gas bench was developed in our laboratory, specially designed for powdered samples, with the aim to obtain a direct comparison of both reductants. In the case of urea-SCR, the residence time between urea injection zone and the catalytic bed is a key parameter. This work presents the catalytic behaviour in terms of $\mathrm{NOx}$ and $\mathrm{NH}_{3}$ conversions over an oxide based prototype SCR catalyst, in comparison with a patented Fe-exchanged zeolite, for standard and fast conditions.

\section{Materials and Methods}

Two powdered samples were evaluated in this study, an oxide based catalyst and a zeolite based catalyst. The oxide was a modified acidic zirconia provided by Solvay, as proposed in [5]. It is denoted aZr. It was evaluated after hydrothermal ageing at $600^{\circ} \mathrm{C}$ and exhibited a specific surface area of 50 $\mathrm{m}^{2} / \mathrm{g}$. Note that this solid appears very stable since its specific surface area was measured at $47 \mathrm{~m}^{2} / \mathrm{g}$ after hydrothermal ageing at $850^{\circ} \mathrm{C}$. The second evaluated catalyst was a patented Fe-zeolite catalyst 
[6], denoted as Fe-zeo. Before use, the catalysts were sieved in the $0.1-0.25 \mathrm{~mm}$ range and the apparent densities were approximately $0.77 \mathrm{~g} \mathrm{~cm}^{3}$ and $0.29 \mathrm{~g} \mathrm{~cm}^{3}$ for aZr and Fe-zeo, respectively.

The DeNOx efficiency was evaluated in "standard SCR" and "fast-SCR" conditions using the following mixture: 400 ppm NOx (i.e. 400 ppm NO in standard-SCR, or 200 ppm NO+200 ppm NO in fast-SCR), $200 \mathrm{ppm}$ urea or $400 \mathrm{ppm} \mathrm{NH}_{3}, 10 \% \mathrm{O}_{2}, 8 \% \mathrm{H}_{2} \mathrm{O}, 10 \% \mathrm{CO}_{2}$ (total flow rate $20 \mathrm{~L}^{\mathrm{h}} \mathrm{h}^{-1}$ ). For water and urea addition, an aqueous solution containing urea $\left(1.3310^{-1} \mathrm{M}\right.$, i.e. $\left.0.794 \mathrm{wt} \%\right)$ was vaporized via a micronozzle $(\varnothing=50 \mu \mathrm{m})$ into a heated zone at $200^{\circ} \mathrm{C}$ upstream the catalytic bed. The liquid flow rate $(19 \mu \mathrm{L}$.min 1) was controlled by a HPLC micro pump ( $\triangle \mathrm{P}=9-10$ bar). The catalyst $(100 \mathrm{mg})$ was placed in a quartz reactor and positioned in an electric furnace. The residence time (noted $\mathrm{Tr}$, corresponding to the elapsed time for the gaseous mixture between urea injection zone and the catalytic bed) was varied between 6.1 $\mathrm{s}$ and $4.0 \mathrm{~s}$ depending on the location of the catalytic bed in the oven. Note that the velocity of the urea ejection at the nozzle outlet is not taken into account for the $\operatorname{Tr}$ calculation. A scheme of the experimental bench is presented in Online Resource 1.

Supplementary tests were performed in order to evaluate the behaviour of materials in the oxidation of $\mathrm{NH}_{3}$ or urea. Selective catalytic oxidation (SCO) tests were performed with the same mixture as for SCR tests, except that NOx were removed. All catalytic activities were evaluated in the $200-500^{\circ} \mathrm{C}$ temperature range, by step of $50^{\circ} \mathrm{C}$. Reported data were recorded after stabilization. The gas composition was monitored with a MKS 2030 Multigas infrared analyser for $\mathrm{NO}, \mathrm{NO}_{2}, \mathrm{~N} 2 \mathrm{O}, \mathrm{HNCO}, \mathrm{NH}_{3}$, $\mathrm{CO}, \mathrm{CO}_{2}$ and $\mathrm{H}_{2} \mathrm{O}$. The urea conversion was calculated taking into account that the introduced urea is fully converted into $\mathrm{NH}_{3}$ at the analyser level without catalyst.

$\mathrm{NH}_{3}$-TPD were performed under a flow containing $\mathrm{CO}_{2}, \mathrm{O}_{2}$ and $\mathrm{H}_{2} \mathrm{O}$ (each at $10 \%$ ) balanced in $\mathrm{N}_{2}$ from $120^{\circ} \mathrm{C}$ up to $550^{\circ} \mathrm{C}\left(5^{\circ} / \mathrm{min}\right)$ after adsorption and purge at $100^{\circ} \mathrm{C}$.

\section{Results and Discussion}

The aim of the study was to evaluate SCR catalysts at the laboratory scale with the on-board reductant: an urea aqueous solution. However, the conversion obtained with gaseous ammonia ( $\left.\mathrm{NH}_{3}-\mathrm{SCR}\right)$ using the same apparatus is required as reference for the direct comparison of both reductant. Results are presented in the next section.

\section{1 $\mathrm{NH}_{3}-\mathrm{SCR}$.}

$\mathrm{NOx}$ and $\mathrm{NH}_{3}$ conversions obtained in standard SCR condition (only NO as NOx inlet) using ammonia as reductant agent are reported in Fig. 1.

Over the zirconia based catalyst (aZr), the NOx conversion starts at $48 \%$ at $200^{\circ} \mathrm{C}$, it reaches a maximum of $93 \%$ near $350^{\circ} \mathrm{C}$ and it then decreases slowly to $87 \%$ at $500^{\circ} \mathrm{C}$. Taking into account the ammonia conversion depicted in Fig.1B, it appears that the $\mathrm{NH}_{3}$ conversion / NOx conversion ratio is very close to 1 until $400^{\circ} \mathrm{C}$, indicating that the DeNOx process respects the fast and/or standard SCR stoichiometry (Eq. 1 and 2). For higher temperatures, this ratio increases and reaches 1.16 at $500^{\circ} \mathrm{C}$ (Fig. 1C). This $\mathrm{NH}_{3}$ over-conversion at high temperatures is explained by the $\mathrm{NH}_{3}$ oxidation by $\mathrm{O}_{2}$ [7]. 

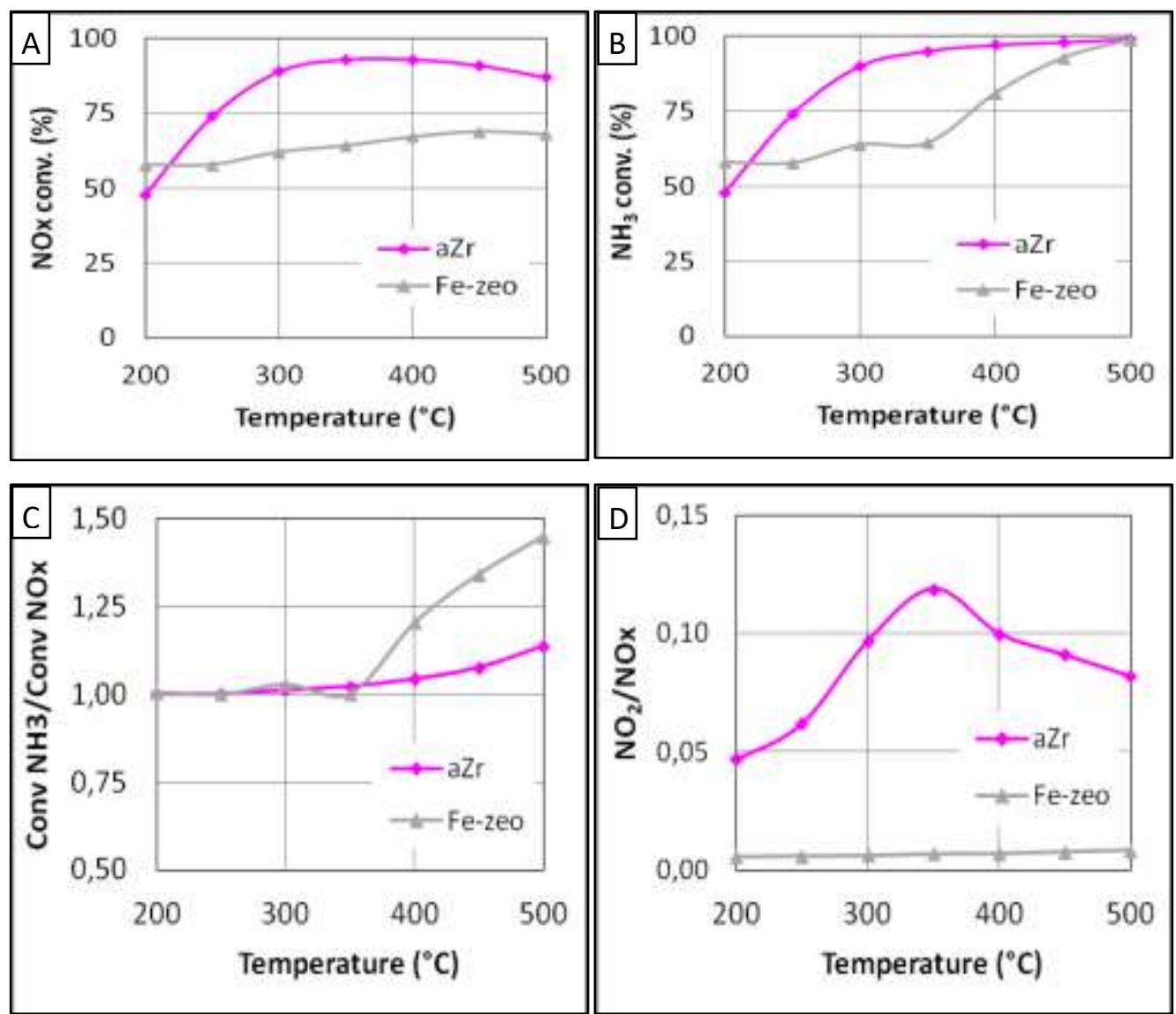

Fig. 1 standard-SCR activity obtained with gaseous $\mathrm{NH}_{3}$ as introduced reductant over aZr ( - ) and Fezeo $(-)$ catalysts. NOx conversion (A), $\mathrm{NH}_{3}$ conversion (B), NOx conversion / $\mathrm{NH}_{3}$ conversion ratio (C), and $\mathrm{NO}_{2} / \mathrm{NOx}$ outlet ratio (D)

In this standard SCR condition, a lower NOx conversion is observed with the Fe-zeo sample compared with aZr. The NOx conversion slowly increases with temperature, it varies between $58 \%$ and $69 \%$ in the $200-500^{\circ} \mathrm{C}$ temperature range, with a maximum at $450^{\circ} \mathrm{C}$. The $\mathrm{NH}_{3}$ conversion is equal to the $\mathrm{NOx}$ conversion until $350^{\circ} \mathrm{C}$, but the $\mathrm{NH}_{3}$ conversion significantly differs for higher temperature, reaching $100 \%$ at $500^{\circ} \mathrm{C}$. The " $\mathrm{NH}_{3}$ conversion / NOx conversion" ratio was then 1.45 (Fig. 1C). It can be attributed to a pronounced oxidation of $\mathrm{NH}_{3}$, most meaningful than over the acidic zirconia.

Comparison of both catalysts also shows that nearly no $\mathrm{NO}_{2}$ is emitted outlet with Fe-zeo (Fig. 1D) whereas 5-10 ppm NO 2 are detected using aZr. One assumption can be a lower activity in the oxidation of $\mathrm{NO}$ to $\mathrm{NO}_{2}$ of Fe-zeo, but in can be also attributable to a full consumption of the generated $\mathrm{NO}_{2}$ by a fast-SCR stoichiometry (eq. 2). In fact, Fe-zeo exhibited high DeNOx efficiency in fast-SCR condition (section 3.2.3), and NO oxidation tests performed at $200^{\circ} \mathrm{C}$ showed that the exchanged zeolite is more active than the aZr oxide based sample: the $\mathrm{NO}$ oxidation into $\mathrm{NO}_{2}$ reached $25 \%$ and almost $0 \%$, respectively (tests not shown). Then, it confirms the preferential fast SCR stoichiometry pathway for NOx reduction on this zeolite material. 


\subsection{Urea-SCR.}

\subsubsection{Standard-SCR condition}

Urea-SCR tests were firstly performed in "standard" conditions with various residence times ( $\mathrm{Tr}$ ) between the urea injector and the catalytic bed. For both studied catalysts, results obtained with residence time of $6.1 \mathrm{~s}$ (not shown) or $5.2 \mathrm{~s}$ are very close to those obtained with gaseous ammonia (Fig. 2). Taking into account that $\mathrm{NH}_{3}$ is assumed to be the effective reductant, these results suggest that $\mathrm{NH}_{3}$ is sufficiently available to ensure the expected NOx reduction.

On the opposite, the NOx reduction can be affected when the residence time is decreased to $4.0 \mathrm{~s}$, especially with the aZr catalyst at low temperatures (Fig. 2A). For instance, the NOx conversion is two times lower at $250^{\circ} \mathrm{C}$. On the opposite, this limitation was not clearly evidenced over Fe-zeo (Fig. 2B). This direct comparison between reductant agents $\left(\mathrm{NH}_{3}\right.$ vs. urea) and catalyst composition illustrates that at least a part of the successive reaction of urea decomposition (Eqs. 3, 4) can be catalysed. Moreover, even if the considered residence times are significantly higher than in real SCR process, a residence time of $4.0 \mathrm{~s}$ appears sufficiently low in the used experimental setup to highlight significant differences depending on the introduced reductant and the catalysts formulation.

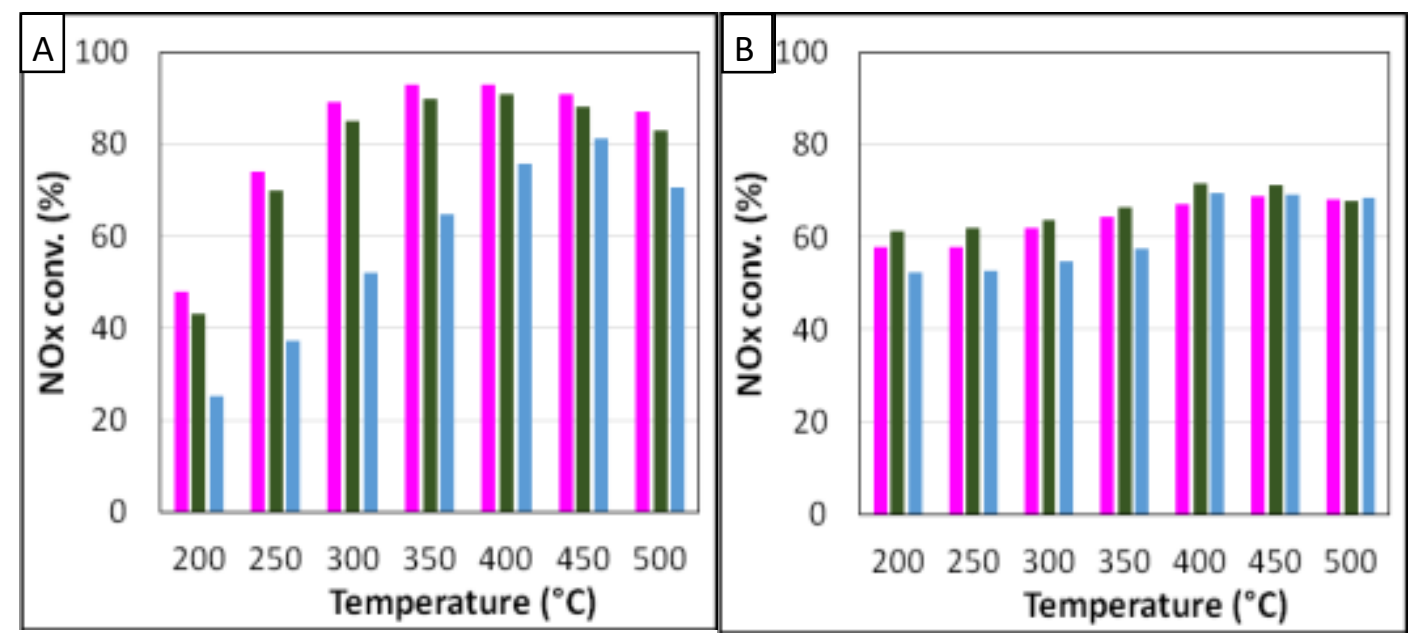

Fig. 2 Influence of urea residence time ( $\square: \operatorname{Tr}=5.2 \mathrm{~s}$; $\square: \mathrm{Tr}=4.0 \mathrm{~s}$.) in "standard-SCR" condition compared with the use of gaseous $\mathrm{NH}_{3}(\square)$. (A) aZr catalyst, (B) Fe-zeo catalyst.

Various hypothesis can be proposed to explain the drop in DeNOx efficiency observed with the acidic zirconia catalyst for shorter urea residence time: (i) a catalyst poisoning due to deposit formation, as presented in the introduction section [2]; (ii) a lack of available $\mathrm{NH}_{3}$ due to incomplete urea decomposition and/or HNCO hydrolysis (eq. 3 and 4); (iii) a lack of available $\mathrm{NH}_{3}$ due to reactivity of the reductant(s) without NOx reduction; (iv) a change in the SCR stoichiometry (attributable for instance to the following reactions $4 \mathrm{NH}_{3}+3 \mathrm{NO}_{2} \rightarrow 3.5 \mathrm{~N}_{2}+6 \mathrm{H}_{2} \mathrm{O}$ and/or $4 \mathrm{NH}_{3}+2 \mathrm{NO}_{2}+\mathrm{O}_{2} \rightarrow 3 \mathrm{~N}_{2}+6 \mathrm{H}_{2} \mathrm{O}$ ).

3.2.2 Investigation of the DeNOx efficiency decrease over aZr catalyst for urea $\mathrm{Tr}=4.0 \mathrm{~s}$.

Additional tests were performed in order to clarify the reason for the loss in NOx conversion over aZr when the residence time dropped to $4.0 \mathrm{~s}$. As the developed apparatus allows the simultaneous use of 
urea and gaseous $\mathrm{NH}_{3}$, it is possible to add gaseous $\mathrm{NH}_{3}$ in the feed stream, in addition to the injection of urea with $\mathrm{Tr}=4.0 \mathrm{~s}$. The amount of added $\mathrm{NH}_{3}$ was calculated to theoretically compensate the loss in NOx conversion for each tested temperature. Results presented in Fig. 3 show that this addition of gaseous $\mathrm{NH}_{3}$ led to a full recovery of the NOx conversion obtained with a residence time of $5.2 \mathrm{~s}$ (full line). Then, the NOx conversion with $\mathrm{Tr}=4.0 \mathrm{~s}$ appears limited by a lack of $\mathrm{NH}_{3}$ availability.

Besides, SCO tests were also carried out to determine the behaviour of materials in the oxidation of the introduced reductant, $\mathrm{NH}_{3}$ or urea $(\mathrm{Tr}=4.0 \mathrm{~s})$. Table 1 reports the reductant conversion expressed in $\mathrm{NH}_{3}$ conversion. It clearly appears that the reductant conversion is significantly improved when urea is used. It is deduced that (i) the effective reactant is not only ammonia when urea is injected, and (ii) the reactive species are more reactive toward oxidation than $\mathrm{NH}_{3}$.

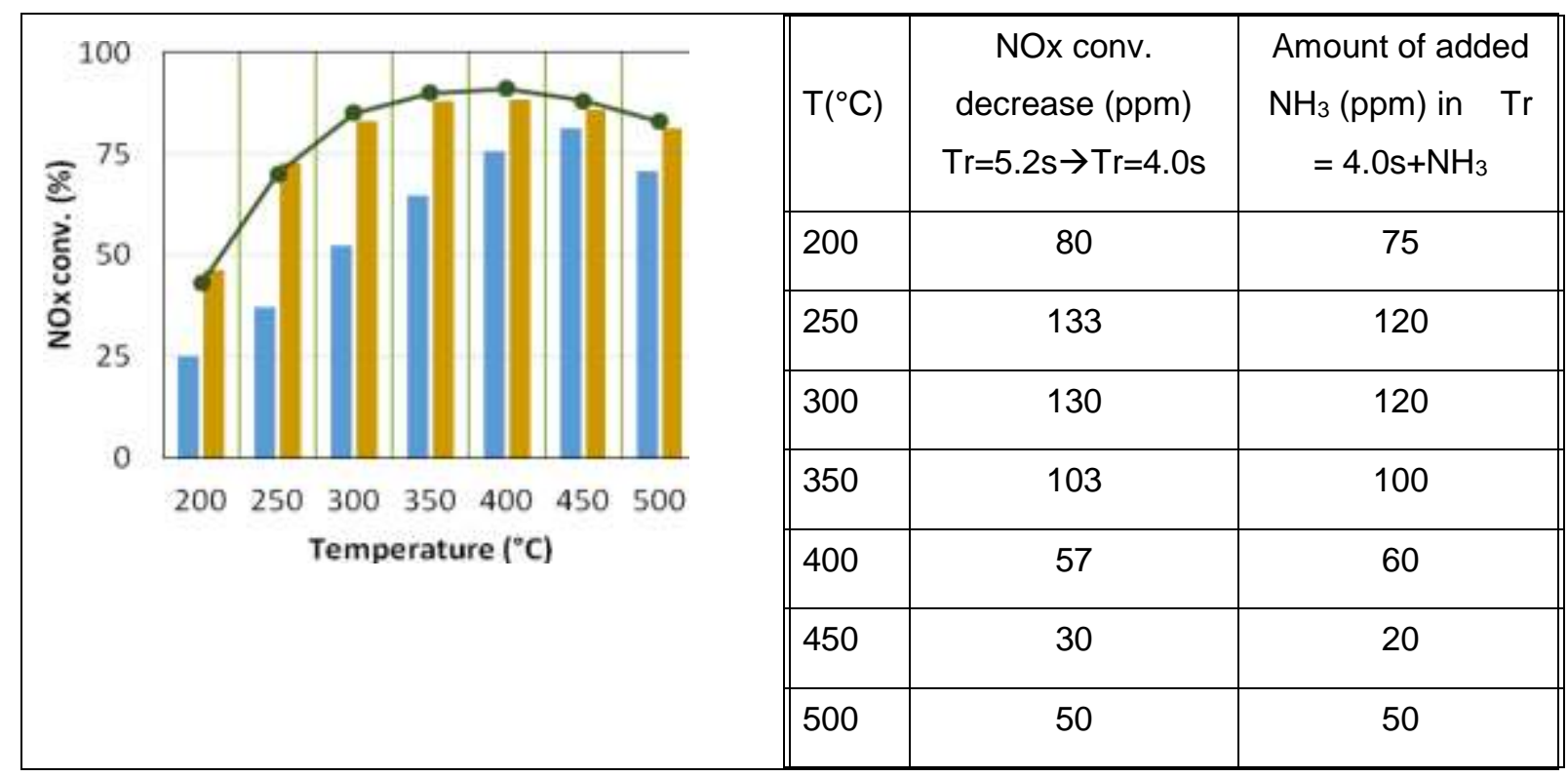

Fig. 3 aZr catalyst: influence of gaseous $\mathrm{NH}_{3}$ addition ( $\square$ ) on the NOx conversion obtained in "standard-SCR" condition with urea $(\square)$ at $\operatorname{Tr}=4.0 \mathrm{~s}$. ( $(-\mathrm{Tr}=5.2 \mathrm{~s}$.)

Table 1: reductant conversion over aZr in Selective Catalytic Oxidation (SCO) test (200 ppm urea or 400 ppm $\mathrm{NH}_{3}, 10 \% \mathrm{O}_{2}, 8 \% \mathrm{H}_{2} \mathrm{O}, 10 \% \mathrm{CO}_{2}$ )

\begin{tabular}{|l|c|c|c|c|c|c|}
\hline Temperature $\left({ }^{\circ} \mathrm{C}\right)$ & 200 & 250 & 300 & 350 & 400 & 450 \\
\hline $\mathrm{NH}_{3}$ conv. (\%) with gaseous $\mathrm{NH}_{3}$ & 0 & 5 & 8 & 15 & 28 & 47 \\
\hline " $\mathrm{NH}_{3}$ " conv. (\%) with urea ( $\left.\mathrm{Tr}=4.0 \mathrm{~s}\right)$ & 0 & 19 & 30 & 31 & 38 & 49 \\
\hline
\end{tabular}



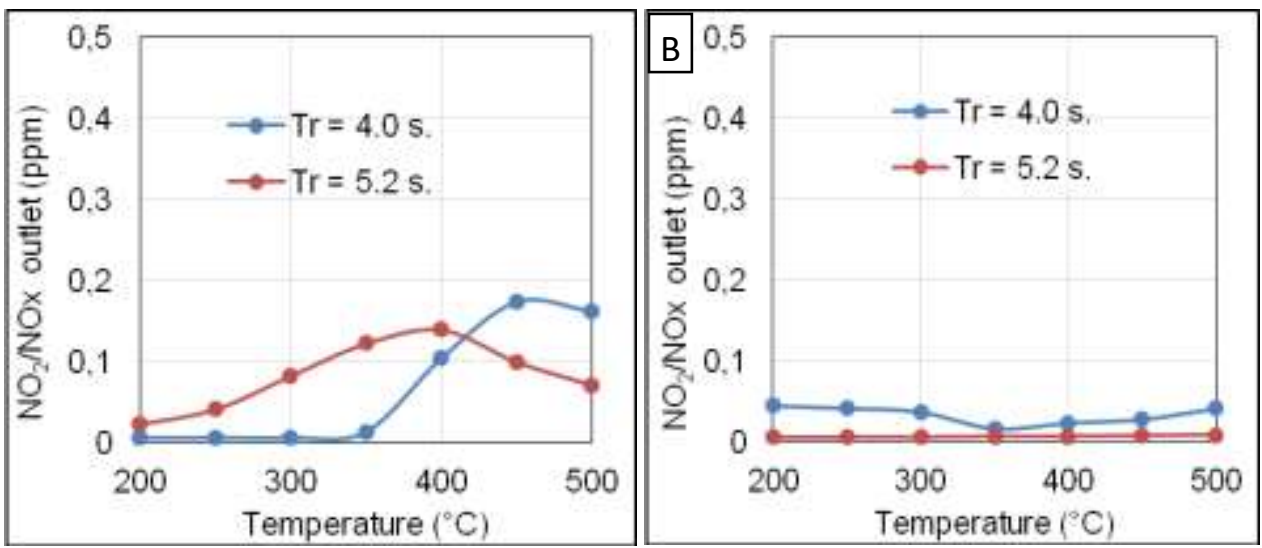

Fig. $4 \mathrm{NO}_{2} / \mathrm{NOx}$ outlet ratio in "standard-SCR" for $\mathrm{Tr}=4.0 \mathrm{~s}(-)$ and $\mathrm{Tr}=5.2 \mathrm{~s}$. (-). (A) aZr catalyst, (B) Fe-zeo catalyst

In addition, the urea residence time can also affect the $\mathrm{NO}_{2} / \mathrm{NOx}$ outlet ratio, depending on the catalyst formulation. For the exchanged zeolite, no clear effect of the urea residence time is observed in $\mathrm{NO}_{2} / \mathrm{NOx}$ outlet ratio (Fig. 4B). In fact, very low amount of $\mathrm{NO}_{2}$ was emitted, whatever the urea residence time. These results are also in accordance with the test performed with gaseous ammonia (Fig. 1D). On the acidic zirconia sample, $\mathrm{NO}_{2}$ can be emitted at low temperature for $\mathrm{Tr}=5.2 \mathrm{~s}$ (Fig. 4A) or using gaseous ammonia (Fig. 1D). On the contrary, no $\mathrm{NO}_{2}$ was emitted until $350^{\circ} \mathrm{C}$ for the shorter urea residence time $(4.0 \mathrm{~s})$. It can be then supposed that the in situ produced $\mathrm{NO}_{2}$ reacted with a product from the urea injection.

These results appear consistent with the previously detailed SCO tests which indicated an enhancement in the oxidation behaviour over the acidic zirconia catalyst when urea was injected with $\mathrm{Tr}=4.0$ s instead of gaseous $\mathrm{NH}_{3}$. The intermediate species, probably $\mathrm{HNCO}$, is not only more reactive toward $\mathrm{O}_{2}$, but also probably toward $\mathrm{NO}_{2}$ (without $\mathrm{NOx}$ reduction).

\subsubsection{Fast-SCR condition}

The detrimental effect of urea residence time on NOx abatement was also examined in more favourable conditions for the NOx reduction, namely the fast-SCR condition. Corresponding catalytic results for both samples are presented in Fig. 5. It appears that the NOx conversion with Fe-zeo is then higher than over aZr. In fact, the NOx conversion was highly improved over Fe-zeo in fast SCR condition compared with the standard SCR condition. It reached $87-97 \%$ in the whole studied temperature range, whatever the introduced reductant, gaseous ammonia or urea with $\operatorname{Tr}=5.2-4.0 \mathrm{~s}$.

The NOx conversion is also improved with aZr in fast-SCR condition, which is particularly evidenced at low temperature: at $200^{\circ} \mathrm{C}$, the NOx conversion reached $68 \%$ in fast-SCR condition (Fig. 5B), compared to $48 \%$ in standard condition (Fig. $2 \mathrm{~A}$ ). 


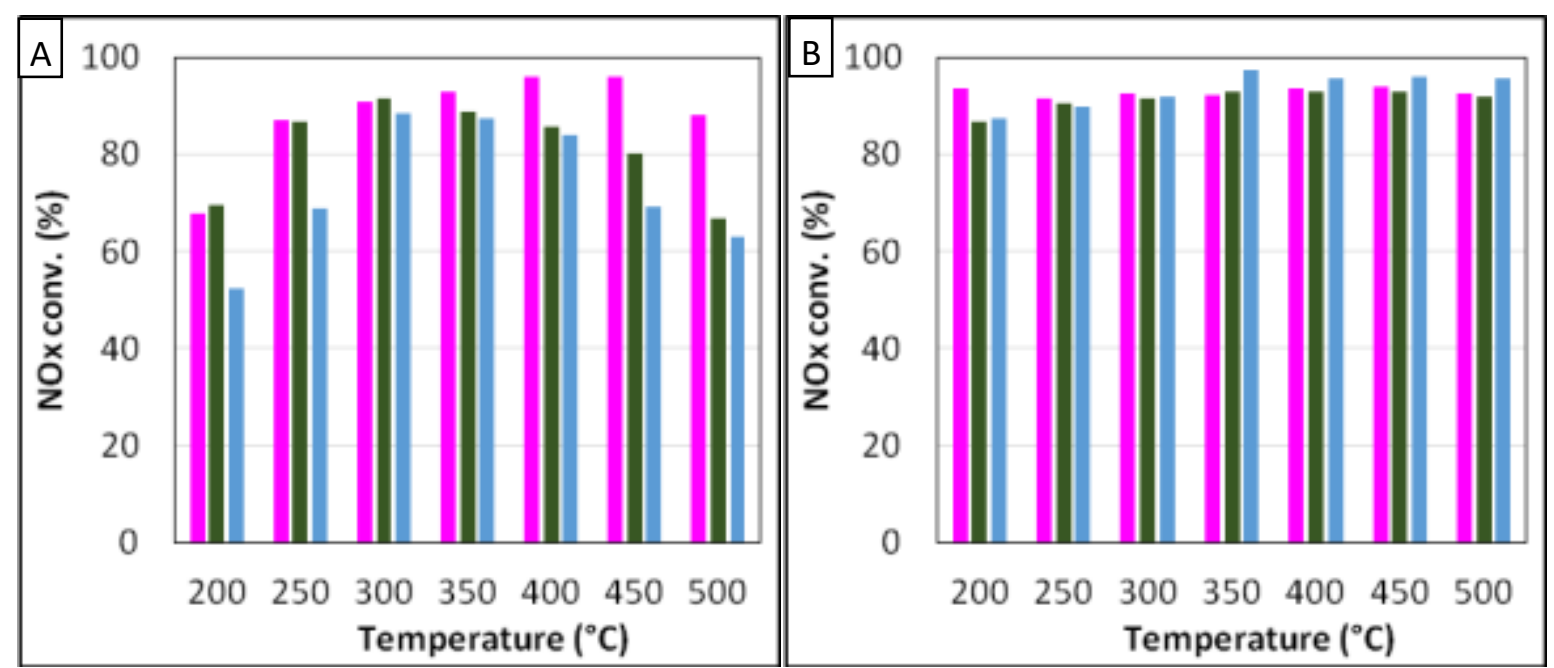

Fig. 5 Influence of urea residence time ( $\square: \operatorname{Tr}=5.2 \mathrm{~s}$.; $\square: \operatorname{Tr}=4.0 \mathrm{~s}$.) in "fast-SCR" condition compared with the use of gaseous $\mathrm{NH}_{3}(\square)$. (A) aZr catalyst, (B) Fe-zeo catalyst

In addition, the detrimental impact of the shorter urea residence time is put in evidence again over the oxide-based sample, with a relative drop of about $25 \%$ at $200^{\circ} \mathrm{C}$. Interestingly, the decrease of the urea residence time still has no influence over Fe-zeo catalyst. Note that the maximum $\mathrm{N}_{2} \mathrm{O}$ outlet concentration is limited to $3 \mathrm{ppm}$ at $500^{\circ} \mathrm{C}$ over aZr, and to $5 \mathrm{ppm}$ at $350^{\circ} \mathrm{C}$ over Fe-zeo (recorded at stabilized temperatures), whatever the inlet condition (standard and/or fast).

\subsubsection{Enhancement of DeNOx efficiency over the acidic zirconia oxide in standard-condition}

Finally, the presented results suggest that the double ammonia formation from urea is not achieved at the catalyst level over the acidic zirconia oxide for shorter urea residence time ( $\operatorname{Tr}=4.0 \mathrm{~s}$.), whatever the SCR conditions, namely standard or fast. The urea thermolysis (Eq. 3) is endothermic and thermally assisted compared to the HNCO hydrolysis which is exothermic. With pure urea, thermal decomposition can occur whereas the isocyanic acid is stable in the gas phase [8]. However, HNCO hydrolysis is catalysed on many solid oxides [9]. It is proposed that the rate of HNCO hydrolysis is much higher than the rate of the SCR reaction at low to medium temperatures on usual SCR catalysts.

However, both Eq. 3 and Eq. 4 reactions can be catalysed by transition metal oxides and the limiting step for ammonia formation also depends on the temperature [10]. Based on the results reported by Berhard et al [10], $100 \mathrm{mg}$ of single oxide $\left(\mathrm{TiO}_{2}, 43 \mathrm{~m}^{2} / \mathrm{g} ; \mathrm{ZrO}_{2}, 46 \mathrm{~m}^{2} / \mathrm{g} ; \mathrm{Al}_{2} \mathrm{O}_{3}, 185 \mathrm{~m}^{2} / \mathrm{g}\right)$ were added just ahead the aZr catalytic bed. These oxides were selected in regards to their respective behaviours in urea thermolysis and HNCO hydrolysis, but they don't exhibit any DeNOx activity (results not shown). The DeNOx efficiencies of these dual bed catalytic systems were evaluated in standard condition.

A partial recovery of the NOx conversion was observed (Table 2) according the following order: $\mathrm{ZrO}_{2}>$ $\mathrm{TiO}_{2}>\mathrm{Al}_{2} \mathrm{O}_{3}$, which also corresponds to the reactivity toward the HNCO hydrolysis reported in [10]. It is concluded that the decrease in the DeNOx efficiency over aZr when the urea $\mathrm{Tr}$ is decreased to $4.0 \mathrm{~s}$ is mainly attributable to a lack in the HNCO hydrolysis. In opposition, Fe-zeo is able to convert HNCO into $\mathrm{NH}_{3}$, or to use directly HNCO to reduce NOx, in both standard and fast SCR conditions. 
Table 2: NOx conversion in standard-SCR condition using urea $(\mathrm{Tr}=4.0 \mathrm{~s})$ as reductant: influence of the single oxide addition $(100 \mathrm{mg}$ ) ahead the aZr catalytic bed.

\begin{tabular}{|l|c|c|c|c|c|c|}
\hline Temperature $\left({ }^{\circ} \mathrm{C}\right)$ & 200 & 250 & 300 & 350 & 400 & 450 \\
\hline NOx conv. (\%) ; aZr catalyst alone & 25 & 37 & 52 & 64 & 75 & 81 \\
\hline NOx conv. (\%); $\mathrm{Al}_{2} \mathrm{O}_{3}+\mathrm{aZr}$ catalyst & 31 & 48 & 58 & 67 & 81 & 83 \\
\hline NOx conv. (\%) ; $\mathrm{TiO}_{2}+\mathrm{aZr}$ catalyst & 27 & 48 & 62 & 71 & 83 & 84 \\
\hline NOx conv. (\%) $\mathrm{ZrO}_{2}+\mathrm{aZr}$ catalyst & 37 & 56 & 72 & 80 & 82 & 82 \\
\hline
\end{tabular}

Additionally, both catalysts present very different acidity behaviour. Ammonia temperature programmed desorption (TPD) were performed in order to evaluate this parameter (profiles not shown). The aZr catalyst presented a maximum desorption near $300^{\circ} \mathrm{C}$, and $\mathrm{NH}_{3}$ desorption was finished at approximately $450^{\circ} \mathrm{C}$. As expected, the zeolite based sample exhibited higher acidic properties: the desorption profile showed a maximum near $400^{\circ} \mathrm{C}$, and it occurred until $570^{\circ} \mathrm{C}$. In addition the amount of desorbed ammonia was approximately two times higher over Fe-zeo than over aZr. This significant difference in acidity strength and site number may intervene in the zeolite behaviour toward $\mathrm{HNCO}$, in accordance with the results obtained with the addition of singles oxides: $\mathrm{ZrO}_{2}$ is the more acidic material compared with $\mathrm{Al}_{2} \mathrm{O}_{3}$ and $\mathrm{TiO}_{2}$.

\section{Conclusions}

This study, carried out at the laboratory scale, clearly demonstrates the interest to evaluate catalysts in urea-SCR rather than in $\mathrm{NH}_{3}$-SCR. A possible divergence in terms of DeNOx efficiency is evidenced depending on the nature of the reductant agent, i.e. gaseous ammonia or aqueous urea, in respect to the catalyst formulation, i.e. oxide or zeolite-based materials. Particularly, the influence of the urea residence time is more detrimental to the acidic zirconia oxide compared to iron exchanged zeolite. In fact, using urea aqueous solution, the evaluated aZr catalyst may not allow an optimal NOx conversion because of a lack in ammonia availability, attributed to insufficient activity in HNCO hydrolysis. The drop in DeNOx efficiency noticed over acidic zirconia sample for shorter urea residence time is evidenced whatever the inlet condition, namely standard or fast SCR. In contrast, the evaluated Fe-zeo did not exhibit such limitations, demonstrating the role of the catalyst in urea-SCR compared to $\mathrm{NH}_{3}-\mathrm{SCR}$ and the interest to develop specific materials active with urea rather than with gaseous ammonia.

In addition, results suggest that $\mathrm{HNCO}$ is more reactive toward oxidation than ammonia over acidic zirconia. In order to highlight this probable inconvenient, SCR tests with excess of $\mathrm{NO}_{2}$ will be investigated in a near future.

\section{Acknowledgment}

The authors gratefully acknowledge the French National Agency for Research (ANR) for its financial support (UreeNOx Project, Ref. ANR-11-VPTT-002). 


\section{References}

1. Kobayashi T, Yamada T, Kayano K (1997) SAE Technical Papers 970745

2. Schaber PM, Colson J, Higgins S, Thielen D, Anspach B, Brauer J (2004) Thermochim. Acta. 424:131-142

3. Koebel M, Elsener M, Kröcher O, Schär C, Röthlisberger R, Jaussi F, Mangold M (2004) Topics Catal. 30/31:43-48

4. Sullivan JA, Doherty JA (2005) Appl. Catal. B. 55:185-194

5. Verdier S, Rohart E, Bradshaw H, Harris D (2008) SAE Technical Paper 2008-01-1022

6. European patent EP2857084

7. Can F, Berland S, Royer S, Courtois X, Duprez D (2013) ACS Catal. 3:1120-1132

8. Koebel M, Elsener M, Kleemann M.(2000) Catal. Today 59:335-235

9. Koebel M., Strutz E.O.(2003) Ind. Eng. Chem. Res. 42:2093-2100

10. Berhard A.M., Peitz D., Elsener M., Schildhauer T., Kröcher O. (2013) Catal. Sc. Technol. 3:942951 